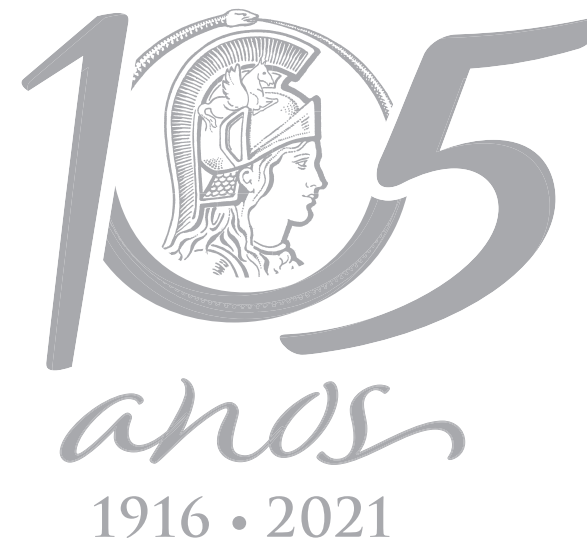

$1916 \cdot 2021$

\title{
ECOSYSTEMS
}

\section{Translocation of Epipelic Biofilms and Their Short-Term Responses to Urbanization Impacts in Nutrient Rich Streams}

\author{
JOAQUÍN COCHERO, MARIAA MERCEDES N. GELIS, JORGE DONADELLI \& NORA \\ GÓMEZ
}

\begin{abstract}
Stream biofilms are among the first to react to environmental degradation, since their structural and functional characteristics are tightly linked to the physicochemical variables in the water and sediment. The objectives of this research were to study the differences in chlorophyll-a, bacterial density and metabolism endpoints of epipelic biofilms in nutrient-rich streams under different physical-chemical conditions in the stream water in relation to changes in urbanization, and to measure the short-term responses (up to $72 \mathrm{~h}$ ) in the biofilm when translocated to more urbanized sites. For these purposes, chlorophyll-a, bacterial density, biofilm respiration (electron transfer activity) and $\mathrm{O}_{2}$ consumption were measured in epipelic biofilms in nutrient-rich streams exposed to different levels of urbanization after a 30 day colonization. Afterward, biofilms were translocated downstream to more polluted sites, and sampled to identify any fast occurring changes to be considered as potential indicators of environmental degradation. Results show that in the nutrient-rich streams studied, the structural characteristics of the biofilm were linked to urbanization, and even after a short time following the translocation, chlorophyll- $a$ and bacterial density varied, reflecting the environmental degradation. On the other hand, metabolic variables were highly variable and produced inconsistent results when representing an increase in urbanization.
\end{abstract}

Key words: Bacterial density, chlorophyll-a, nutrient-rich streams, short term responses, translocation assay,

\section{INTRODUCTION}

The process of urbanization affecting streams and rivers is linked to the effects of multiple simultaneous stressors, the "urban stream syndrome" (Walsh et al. 2005), which confounds the ability to make inferences about the relative effect of each stressor on the biota (Paul \& Meyer 2001, Walsh et al. 2005). Fluvial biofilms (Lock 1981) have been used to monitor physical and chemical water quality changes since the short life cycle of the microorganisms and the trophic interactions between the microbiota allow for the detection of both short and longterm impacts.

These communities are among the first to be affected by the impacts associated to urbanization, including nutrient enrichments (Guasch et al. 1995, Rier \& Stevenson 2002, Olapade \& Leff 2005), heavy metals (Ramelow et al. 1987, Medley \& Clements 1998, Giorgi \& Malacalza 2002), herbicides and pesticides (Dorigo et al. 2007, Tlili et al. 2008, Ricart et al. 2010) and pharmaceutical components (Proia 2012). For these reasons, multiple structural and functional endpoints from the biofilm are employed in water quality monitoring programs 
of both direct and indirect environmental impacts (Proia et al. 2012). For instance, water quality detriments can lead to an increase in algal biomass and algal pigments (Tien et al. 2009), in bacterial growth (Leff 2000, Tien et al. 2009), in metabolic activity (Guasch et al. 1995, Garnier \& Billen 2007), and are usually linked to a modification in the specific composition (Rimet et al. 2009, Delgado et al. 2012).

In environments with high availability of resources, such as the nutrient rich streams of the Pampean region in Argentina, biofilms developing under different water qualities have exhibited differences in biomass and metabolic activity (Feijoó et al. 1999, Bauer et al. 2002, Vilches 2012, Licursi et al. 2016, Cochero et al. 2018). And even after a water quality detriment, some studies have measured responses in long-term responses (>20 days) of certain communities in Pampean streams, such as diatoms (Tolcach \& Gómez 2002, Nicolosi Gelis et al. 2020). However, water quality can change abruptly in urbanized environments, particularly if punctual pollution sources are present, and measuring short-term responses to these environmental changes have to be considered in biomonitoring practices. However, no studies have been conducted in epipelic biofilm from lowland streams, where the predominant substrate are sediments with large contents of silts and clay, that measure their short-term responses to water quality detriments linked to urbanization.

To simulate these environmental impacts, translocation assays (also known as "active biomonitoring") employing biofilms have been used successfully to describe the effects of various environmental and anthropogenic stressors (Ivorra et al. 1999, Guasch et al. 2010a, Sierra \& Gómez 2010, Tlili et al. 2011, Proia et al. 2013, Nicolosi Gelis et al. 2020), yet only a few related to organic pollution in urban streams and the large majority in nutrient-depleted fluvial systems with epilithic substrates. These biomonitoring techniques consist of the transfer of organisms from one place to another to quantifying their biochemical, physiological and/or organismal responses for the purpose of water quality monitoring (De Kock \& Kramer 1994).

The objectives of this research were to study the differences in chlorophyll-a, bacterial density and metabolism endpoints of epipelic biofilms in nutrient-rich streams under different physical-chemical conditions in the stream water in relation to changes in urbanization, and to measure the short-term responses (up to $72 \mathrm{~h}$ ) in the biofilm when translocated to more urbanized sites. We hypothesized that, since the structure and metabolism of biofilms are rapidly affected by the physical-chemical characteristics of the water, they would reflect the environmental changes quickly. In this sense, an increase in organic matter and nutrients after the translocation would be reflected as increments in bacterial density, chlorophyll-a content and in the metabolic activity of the translocated biofilms.

\section{MATERIALS AND METHODS}

\section{Sites selection and physical-chemical data}

Three streams ("Don Carlos" stream, hereafter "Stream 1"; "El Gato" stream, hereafter "Stream 2"; "Rodriguez" stream, hereafter "Stream 3") that run through urbanized areas near the city of La Plata (Argentina) were selected a priori from previous research considering their degree of exposure to urbanization (Cochero et al. 2016, 2018). Briefly, their degree of urbanization of the surrounding land was measured by calculating the percentage of impervious surface in the watershed related to urban activities, by obtaining land-use maps (Instituto Geográfico Nacional, www.ign.gob.ar). All sites had similar 
hydrological characteristics, low velocity $(<0.02$ $\left.\mathrm{m} \mathrm{s}^{-1}\right)$, similar turbidity $(90 \pm 32 \mathrm{NTU})$ and lacked riparian vegetation (trees or shrubs) and macrophytes.

According to that previous evaluation, Stream 1 ("Don Carlos") had the lowest impact due to urbanization, also reflected in lower concentrations of nutrients and organic matter content in the water, lower conductivity and higher dissolved oxygen values. On the other side of the gradient, Stream 3 ("Rodriguez") was detected to be the most heavily impacted by urbanization. This stream runs through a populated area without proper sewage systems, and receives direct industrial effluents, having higher average values of nutrients, organic matter, conductivity and lower dissolved oxygen values.

To conduct the translocation studies at each stream, two sites were selected: a peri-urban site (named "Upstream"), located upstream on the outskirts of the city and exposed to low/ moderate agricultural activities, and a heavily urbanized site (named "Downstream"), within the urbanized area of La Plata city (site coordinates in Figure 1).

In all sampling dates, dissolved Oxygen (DO, $\left.\mathrm{mgL}^{-1}\right)$, temperature $\left({ }^{\circ} \mathrm{C}\right)$, conductivity $\left(\mu \mathrm{S} \mathrm{cm}^{-1}\right)$, $\mathrm{pH}$ and turbidity (NTU) were measured at each site using a multiparametric sensor (Horiba U50). Water samples (500 $\mathrm{ml}$ ) were collected in the Upstream and Downstream sites in order to

\begin{tabular}{|c|c|c|c|c|}
\hline Site & $\begin{array}{c}\text { Colonization period } \\
\text { (30 days) }\end{array}$ & & $\begin{array}{l}\text { Experimental period } \\
\qquad(72 \mathrm{hrs.})\end{array}$ & $\begin{array}{c}\text { Site } \\
\text { Coordinates }\end{array}$ \\
\hline Upstream & $\begin{array}{l} \\
\text { Upstream } \\
\mathbb{Z} \mathbb{Z} \\
\text { Translocated }\end{array}$ & Translocation & Upstream & $\begin{array}{l}\text { Stream } 1 \\
34^{\circ} 53^{\prime} 40.52^{\prime \prime} \mathrm{S} \\
58^{\circ} 1^{\prime} 22.69 " \mathrm{~W} \\
\text { Stream } 2 \\
34^{\circ} 58^{\prime} 47.66^{\prime \prime S} \mathrm{~S} \\
58^{\circ} 3^{\prime} 7.81^{\prime \prime W} \\
\\
\text { Stream } 3 \\
34^{\circ} 53^{\prime} 24.85^{\prime \prime} \mathrm{S} \\
58^{\circ} 2^{\prime} 56.07^{\prime \prime} \mathrm{W}\end{array}$ \\
\hline Downstream & Downstream & & $\begin{array}{l}\text { Downstream } \\
\mathbb{Z} \mathbb{Z} \\
\text { Translocated }\end{array}$ & $\begin{array}{l}\text { Stream } 1 \\
34^{\circ} 54^{\prime} 8.31^{\prime \prime S} \\
58^{\circ} 1^{\prime} 35.39 " \mathrm{~W} \\
\text { Stream } 2 \\
34^{\circ} 57^{\prime} 52.37^{\prime \prime S} \\
58^{\circ} 0^{\prime} 16.96 " \mathrm{~W} \\
\\
\text { Stream } 3 \\
34^{\circ} 55^{\prime} 22.12^{\prime \prime} \mathrm{S} \\
58^{\circ} 4^{\prime} 58.91 " \mathrm{~W}\end{array}$ \\
\hline
\end{tabular}

Figure 1. Experimental design used involving the translocation of germination trays with sediment from an Upstream site to a Downstream site within streams. The Upstream treatment trays (light gray squares) were colonized in the Upstream sites and kept there as controls; the Downstream treatment trays (dark gray squares) were colonized in the Downstream sites and kept there as controls; and the Translocated treatment trays (striped squares) were colonized in the Upstream sites and transferred to the Downstream sites for the experimental period. 
measure ammonium $\left(\mathrm{NH}_{4}^{+}, \mathrm{mgL}^{-1}\right)$, nitrites $\left(\mathrm{NO}_{2}\right.$ , $\left.\mathrm{mgL}^{-1}\right)$, nitrates $\left(\mathrm{NO}_{3}{ }^{-}, \mathrm{mgL}^{-1}\right)$, soluble reactive phosphorous (SRP, $\mathrm{mgL}^{-1}$ ), biochemical oxygen demand $\left(\mathrm{BOD}_{5}, \mathrm{mgL}^{-1}\right)$ and chemical oxygen demand $\left(C O D, \mathrm{mgL}^{-1}\right)$, which were analyzed according to standardized spectrophotometric methods (APHA 2017). Dissolved organic nitrogen (DIN) was calculated as the sum of ammonium, nitrites and nitrates.

\section{Experimental setup}

At each stream, nine germination trays (200 wells, each well 2.5 diameter $\times 3 \mathrm{~cm}$ deep) were filled with stream sediment and attached to the streambed ensuring light penetration and left to be colonized for 30 days to reach a developed, mature biofilm. Within each stream, six of the trays were placed in the Upstream site and the other three trays were placed in the Downstream site to study the responses of biofilms to the physical-chemical characteristics in the water.

Afterward, to measure the rapid changes in the biofilm structure and function when the environmental quality decreases, three of the trays from the Upstream site were transferred in a humid environment to the Downstream site. Therefore, three treatments were established: control trays for the Upstream sites, control trays for the downstream sites and the trays that were transferred from the Upstream to the Downstream sites (named "Translocated treatment") (Figure 1).

At the time of translocation (TO) and every $24 \mathrm{hs}$ post-translocation for $72 \mathrm{hs}(\mathrm{T} 1, \mathrm{~T} 2, \mathrm{~T} 3)$, three epipelic biofilm subsamples were collected at random from each tray by pipetting the surface layer $(0.5 \mathrm{~cm})$ of the sediment (Gómez et al. 2011) and transported to the lab in coolants for analysis. Biological endpoints were measured in all three subsamples from each tray, and their values were averaged for the statistical analyses; therefore, each tray acted as a single experimental unit. Results obtained for the biological endpoints (chlorophyll-a, bacterial density, activity of the electron transport system, additional $\mathrm{O}_{2}$ consumption) were referred to the total surface (in $\mathrm{cm}^{2}$ ) of the sampled sediment by a granulometry analysis (Folk 1959). Briefly, $1 \mathrm{~g}$ of dry sediment was sieved and separated into clay $(<3.9 \mu \mathrm{m})$, silt $(3.9$ to $<62.5 \mu \mathrm{m})$, fine/ very fine sand ( 62.5 to $<250 \mu \mathrm{m})$, medium sand $(250$ to $<500 \mu \mathrm{m})$, and coarse sand $(>500 \mu \mathrm{m})$. The total surface for each size fraction was then calculated assuming the surface of a spherical shape for the grains and the density of silica $\left(2.65 \mathrm{~g} \mathrm{~cm}^{-3}\right)$, to obtain a conversion factor for each stream reach.

\section{Bacterial density}

Samples were stored in sterile glass vials with $2 \% \mathrm{v} / \mathrm{v}$ formalin. Bacterial density was estimated after sonication (three 2 min cycles) and appropriate dilution (1:100 to 1:400) of the samples. Diluted samples were stained for 10 min with DAPI (4', 6-diamidino-2-phenyilindole) to a final concentration of $1 \mu \mathrm{g} \mathrm{mL} \mathrm{L}^{-1}$ (Porter \& Feig 1980), and filtered through a $0.2 \mu \mathrm{m}$ black polycarbonate filter (GE Osmonics). Bacteria were then counted using an epifluorescence microscope (Olympus BX-50) under 1000× magnification and with an Olympus Q-Color5 imaging system. Twenty fields per replicate were counted for a total of 400 to 800 organisms.

\section{Chlorophyll-a}

Chlorophyll-a content was measured by spectrophotometric methods. Samples were first sonicated for three 2-minute cycles in a Cleanson CS1106 sonicator and filtered through Sartorious GF/C filters. Chlorophyll-a was extracted with $90 \%$ acetone for $12 \mathrm{~h}$ and the supernatant was read in a Labomed UV-VIS Auto 2602 spectrophotometer. Chlorophyll-a 
concentration ( $\mathrm{mg} \mathrm{cm}^{-2}$ ) was calculated according to Strickland \& Parsons (1972).

\section{Activity of the electron transport system (ETS)}

The ETS activity represents a measure of the overall respiration of the biofilm, and was assayed by measuring the reduction of the electron transport acceptor INT (2-3 tetrazolium chloride) into INT-formazan (iodonitrotetrazolium formazan) (Blenkinsopp \& Lock 1990). Samples were incubated in $0.02 \%$ INT solution (SigmaAldrich) for 12 hours in the dark. INT-formazan was then extracted with cold methanol for a minimum of $1 \mathrm{~h}$ at 4 으 in the dark followed by sonication (Cleanson CS1106). Absorbance at 480 $\mathrm{nm}$ was measured in a Labomed UV-VIS Auto 2602 spectrophotometer and converted to ETS activity values ( $\mu$ g INT-formazan $\mathrm{cm}^{-2} \mathrm{~h}^{-1}$ ) using a stock solution of $30 \mathrm{mg} \mathrm{mL}^{-1}$ INT-formazan in methanol.

\section{Additional oxygen consumption of the sediment}

The additional oxygen consumption method (Knopp 1968) uses a substrate to stimulate bacterial growth (peptone) in the samples, and assumes that if the bacterial activity is normal, the respiration associated with the reduction of the additional substrate leads to an increased oxygen consumption. This can be measured as a greater oxygen depletion at the end of an incubation period. If bacteria are being inhibited by a stressor, oxygen consumption ceases or lowers significantly. The additional oxygen consumption (or "ZZ", for its acronym in German) therefore provides a fast and comparative measurement of the overall bacterial respiratory activity. In these assays, samples were incubated for $24 \mathrm{hs}$ after a peptone (50 $\mathrm{mg} \mathrm{L}^{-1}$ ) spike was added, and the dissolved oxygen consumed was compared to control samples without peptone. Results are expressed as the amount of oxygen consumed by the biofilm per hour $\left(\mathrm{mg} \mathrm{O} \mathrm{O}_{2} \mathrm{~cm}^{-2}\right.$ $\left.h^{-1}\right)$.

\section{Statistical analyses}

Differences in physical-chemical characteristics of the sites were analyzed by a two factor Multivariate Analysis of Variance (MANOVA; Stream: Stream 1, Stream 2, Stream 3; Site: Upstream, Downstream).

Changes in each of the biological variables in the biofilm were analyzed by means of a nested analysis of variance (Stream: Stream 1, Stream 2, Stream 3; Treatment: Upstream, Downstream, Translocated; Time: T0, T1, T2, T3), following the model: $[X=\mu+$ Stream + Treatment (Stream) + Time + Stream * Time + Time * Treatment $($ Stream $)+$ Residuals].

Values were first transformed to $\log (x+1)$ to ensure normality, which was previously assessed by the Shapiro-Wilk test (Shapiro \& Wilk 1965); homogeneity of variance was tested by Cochran's C test (Cochran 1951). For each biological variable, three subsamples from each tray were collected, and their mean value was used for the statistical analyses. The StudentNewman-Keuls (SNK) post-hoc test was used, and partial eta ${ }^{2}\left(\eta^{2}\right)$ was computed as a measure of the effect size. The relationship between biotic variables and physical-chemical characteristics of the sampled sites were first checked by a correlation analysis and modeled by applying generalized linear models (GLMs), considering a Gaussian distribution after checking that the residuals were normally distributed.

All analyses were conducted using R (3.5.2) in RStudio (1.2.5033). The rstatix package was used to test normality and the outliers, to conduct the ANOVA and RM-ANOVA analyses. The agricolae package was used for the a posteriori tests and ggplot2 for plotting. 


\section{RESULTS}

\section{Site characteristics and physical-chemical data}

Results show a higher impact of urbanization in Stream 3, evidenced as higher mean values of SRP $\left(1.85 \pm 1.37 \mathrm{mg} \mathrm{L}^{-1}\right)$, followed by Stream $2(0.47$ $\left.\pm 0.25 \mathrm{mg} \mathrm{L}^{-1}\right)$ and Stream $1\left(0.40 \pm 0.03 \mathrm{mg} \mathrm{L}^{-1}\right)$. In the same gradient, Stream 3 had higher mean values of organic matter, indicated by values of $\mathrm{BOD}_{5}\left(16.0 \pm 6.80 \mathrm{mg} \mathrm{L}^{-1}\right)$ and COD $(31.7 \pm 14.7 \mathrm{mg}$ $\left.\mathrm{L}^{-1}\right)$, followed by Stream $2\left(\mathrm{BOD}_{5} 9.6 \pm 5.2 \mathrm{mg} \mathrm{L}^{-1}\right.$;
COD $\left.19.5 \pm 6.4 \mathrm{mg} \mathrm{L}^{-1}\right)$ and Stream $1\left(\mathrm{BOD}_{5} 9.0 \pm 3.4\right.$ $\mathrm{mg} \mathrm{L}^{-1}$; COD $19.1 \pm 5.4 \mathrm{mg} \mathrm{L}^{-1}$ ).

When considering the sites within each stream, results from the multivariate analyses show a significant increment in nutrients and organic matter concentrations from the Upstream to the Downstream sites (Table I), depending on the analyzed Stream (Stream ${ }^{\star}$ Treatment $p=0.012$; partial $\left.\eta^{2}=0.84\right)$. In Stream 1, the Downstream site had higher concentrations of SRP $(+8.6 \%)$, $\mathrm{BOD}_{5}(+36.4 \%)$ and COD (+40.3\%). In Stream 2, the Downstream site had increased concentrations

Table I. Mean ( \pm Standard deviation) values for the physical-chemical data in the upstream (Up) and downstream (Down) sites of each stream $(1,2,3)$. Significant differences between sites are marked with * $(p$-value $<0.05)$.

\begin{tabular}{|c|c|c|c|c|c|c|c|c|c|}
\hline & \multicolumn{3}{|c|}{ Stream 1} & \multicolumn{3}{|c|}{ Stream 2} & \multicolumn{3}{|c|}{ Stream 3} \\
\hline & Up & Down & p-value & Up & Down & p-value & Up & Down & p-value \\
\hline$\underset{\left(\mathrm{mg} \mathrm{L}^{-1}\right)}{\mathbf{S R P}}$ & $\begin{array}{c}0.39 \\
( \pm 0.0) \\
\end{array}$ & $\begin{array}{c}0.42 \\
( \pm 0.0)\end{array}$ & $0.03^{*}$ & $\begin{array}{c}0.21 \\
( \pm 0.0)\end{array}$ & $\begin{array}{c}0.64 \\
( \pm 0.1)\end{array}$ & $<0.01 *$ & $\begin{array}{c}0.60 \\
( \pm 0.0)\end{array}$ & $\begin{array}{c}3.11 \\
( \pm 0.2)\end{array}$ & $<0.01 *$ \\
\hline $\begin{array}{l}\mathbf{N O}_{3}^{-} \\
\left(\mathrm{mg} \mathrm{L}^{-1}\right)\end{array}$ & $\begin{array}{c}0.88 \\
( \pm 0.0)\end{array}$ & $\begin{array}{c}1.14 \\
( \pm 0.2)\end{array}$ & 0.57 & $\begin{array}{c}0.84 \\
( \pm 0.4)\end{array}$ & $\begin{array}{c}1.81 \\
( \pm 0.5)\end{array}$ & $0.03^{*}$ & $\begin{array}{c}0.29 \\
( \pm 0.1)\end{array}$ & $\begin{array}{c}0.39 \\
( \pm 0.1)\end{array}$ & $0.62^{*}$ \\
\hline $\begin{array}{c}\mathbf{N O}_{2}^{-} \\
\left(\mathrm{mg} \mathrm{L}^{-1}\right)\end{array}$ & $\begin{array}{c}0.18 \\
( \pm 0.0)\end{array}$ & $\begin{array}{c}0.21 \\
( \pm 0.0)\end{array}$ & 0.50 & $\begin{array}{c}0.04 \\
( \pm 0.0)\end{array}$ & $\begin{array}{c}0.08 \\
( \pm 0.0)\end{array}$ & 0.26 & $\begin{array}{c}0.04 \\
( \pm 0.0) \\
\end{array}$ & $\begin{array}{c}0.27 \\
( \pm 0.0)\end{array}$ & $0.01^{*}$ \\
\hline $\begin{array}{c}\mathbf{N H}_{4}^{+} \\
\left(\mathrm{mg} \mathrm{L}^{-1}\right)\end{array}$ & $\begin{array}{c}1.28 \\
( \pm 0.4)\end{array}$ & $\begin{array}{c}0.70 \\
( \pm 0.6)\end{array}$ & 0.14 & $\begin{array}{l}0.14 \\
( \pm 0)\end{array}$ & $\begin{array}{l}0.25 \\
( \pm 0)\end{array}$ & 0.58 & $\begin{array}{l}0.07 \\
( \pm 0)\end{array}$ & $\begin{array}{c}1.11 \\
( \pm 0.3)\end{array}$ & $0.01 *$ \\
\hline $\begin{array}{c}\text { DIN } \\
\left(\mathrm{mg} \mathrm{L}^{-1}\right)\end{array}$ & $\begin{array}{c}2.35 \\
( \pm 0.5)\end{array}$ & $\begin{array}{c}2.06 \\
( \pm 0.8) \\
\end{array}$ & 0.65 & $\begin{array}{c}1.02 \\
( \pm 0.3) \\
\end{array}$ & $\begin{array}{c}2.14 \\
( \pm 0.5) \\
\end{array}$ & $0.04^{*}$ & $\begin{array}{l}0.40 \\
( \pm 0.1)\end{array}$ & $\begin{array}{c}1.76 \\
( \pm 0.3)\end{array}$ & $0.03^{*}$ \\
\hline $\begin{array}{c}\mathbf{B O D}_{5} \\
\left(\mathrm{mg} \mathrm{L}^{-1}\right)\end{array}$ & $\begin{array}{c}7 \\
( \pm 2.6) \\
\end{array}$ & $\begin{array}{c}11 \\
( \pm 2) \\
\end{array}$ & $0.03^{*}$ & $\begin{array}{l}7.3 \\
( \pm 3) \\
\end{array}$ & $\begin{array}{c}12 \\
( \pm 2.5)\end{array}$ & $0.02 *$ & $\begin{array}{c}10.5 \\
( \pm 0.6) \\
\end{array}$ & $\begin{array}{c}21.5 \\
( \pm 2.5)\end{array}$ & $0.04^{*}$ \\
\hline $\begin{array}{c}\text { COD } \\
\left(\mathrm{mg} \mathrm{L}^{-1}\right)\end{array}$ & $\begin{array}{c}14.3 \\
( \pm 1.2) \\
\end{array}$ & $\begin{array}{l}24 \\
( \pm 2) \\
\end{array}$ & $0.02 *$ & $\begin{array}{c}19 \\
( \pm 3.2) \\
\end{array}$ & $\begin{array}{c}20 \\
( \pm 5.3) \\
\end{array}$ & 0.98 & $\begin{array}{c}24.8 \\
( \pm 8.2) \\
\end{array}$ & $\begin{array}{l}38.8 \\
( \pm 5.2) \\
\end{array}$ & 0.59 \\
\hline $\begin{array}{c}\text { Temperature } \\
\left({ }^{\circ} \mathrm{C}\right)\end{array}$ & $\begin{array}{c}12.5 \\
( \pm 0.3)\end{array}$ & $\begin{array}{c}12 \\
( \pm 0.2)\end{array}$ & 0.71 & $\begin{array}{c}8.9 \\
( \pm 0.5)\end{array}$ & $\begin{array}{c}12.4 \\
( \pm 0.3)\end{array}$ & $0.02 *$ & $\begin{array}{c}13.3 \\
( \pm 0.8)\end{array}$ & $\begin{array}{c}15.7 \\
( \pm 0.9)\end{array}$ & 0.18 \\
\hline $\mathrm{pH}$ & $\begin{array}{c}8.1 \\
( \pm 0.1)\end{array}$ & $\begin{array}{c}7.9 \\
( \pm 0.1) \\
\end{array}$ & 0.11 & $\begin{array}{c}7.2 \\
( \pm 0.1) \\
\end{array}$ & $\begin{array}{c}7.7 \\
( \pm 0.1) \\
\end{array}$ & 0.10 & $\begin{array}{c}7.4 \\
( \pm 0.1) \\
\end{array}$ & $\begin{array}{c}7.8 \\
( \pm 0.1) \\
\end{array}$ & 0.16 \\
\hline Turbidity (NTU) & $\begin{array}{c}44.2 \\
( \pm 9.4)\end{array}$ & $\begin{array}{l}37.3 \\
( \pm 8.2)\end{array}$ & 0.88 & $\begin{array}{c}154.5 \\
( \pm 34.5)\end{array}$ & $\begin{array}{c}61.7 \\
( \pm 23.3)\end{array}$ & 0.10 & $\begin{array}{c}74.9 \\
( \pm 27.8)\end{array}$ & $\begin{array}{c}89.2 \\
( \pm 14.1)\end{array}$ & 0.43 \\
\hline $\begin{array}{l}\text { Conductivity } \\
\left(\mu \mathrm{Sm}^{-1}\right)\end{array}$ & $\begin{array}{c}782.9 \\
( \pm 20.4)\end{array}$ & $\begin{array}{l}781.3 \\
( \pm 19.1)\end{array}$ & 0.88 & $\begin{array}{l}349.5 \\
( \pm 61.2)\end{array}$ & $\begin{array}{c}611.4 \\
( \pm 18.2)\end{array}$ & $0.04^{*}$ & $\begin{array}{c}306.3 \\
( \pm 50.8)\end{array}$ & $\begin{array}{c}950.4 \\
( \pm 90.3)\end{array}$ & $0.01^{*}$ \\
\hline $\begin{array}{c}\text { DO } \\
\left(m g L^{-1}\right)\end{array}$ & $\begin{array}{c}4.2 \\
( \pm 0.2)\end{array}$ & $\begin{array}{c}5.2 \\
( \pm 0.9)\end{array}$ & 0.73 & $\begin{array}{c}6.6 \\
( \pm 0.4)\end{array}$ & $\begin{array}{c}7 \\
( \pm 0.8)\end{array}$ & 0.70 & $\begin{array}{c}6 \\
( \pm 0.9)\end{array}$ & $\begin{array}{c}5.5 \\
( \pm 0.6)\end{array}$ & 0.92 \\
\hline
\end{tabular}


of SRP $(+67.5 \%), \mathrm{BOD}_{5}(+39.6 \%)$, DIN $(+52.4 \%)$ and conductivity values $(+42.8 \%)$. And in Stream 3 , the Downstream site also had significant increments in SRP $(+80.6 \%), \mathrm{BOD}_{5}(+51.2 \%)$, DIN $(+77.4 \%)$ and conductivity values (+67.8\%).

The effect size measure shows that the differences in physical-chemical variables between sites is intermediate (Partial $0.75<\eta^{2}$ $\geq 0.25$ ).

\section{Biofilm structure}

The bacterial density was similar between streams, yet it was higher in all the Downstream sites when compared to the Upstream site
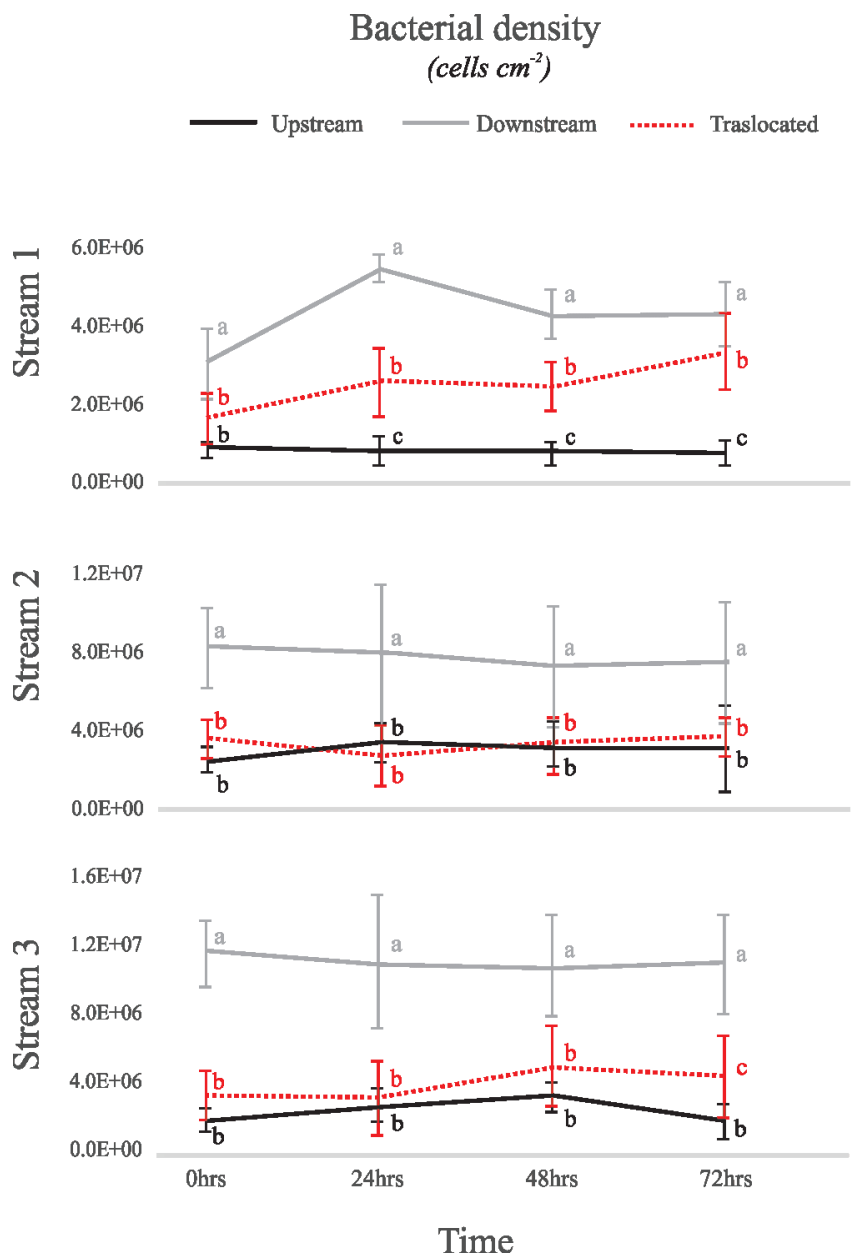

within each stream (Figure 2, Table II). Mean bacterial density increases from Stream 1 to Stream 3, with no significant differences in the analyses: it ranged from $7.27 \times 10^{5}$ to $5.48 \times 10^{6}$ cells $\mathrm{cm}^{-2}$ in Stream 1, from $2.46 \times 10^{6}$ to $8.21 \times 10^{6}$ cells $\mathrm{cm}^{-2}$ in Stream 2 and from $1.66 \times 10^{6}$ to $1.16 \times 10^{7}$ cells $\mathrm{cm}^{-2}$ in Stream 3. The bacterial density in the translocated biofilm in Stream 1 increased from T1 to T3 until it was similar to the density at the Downstream site $(p<0.05)$. In Streams 2 and 3, however, bacterial density in the translocated biofilm was always similar to the one in the Upstream treatment (Figure 2). The effect size measures show that the significant

Chlorophyll- $a$ $\left(\mu \mathrm{g} \mathrm{cm}{ }^{-2}\right)$
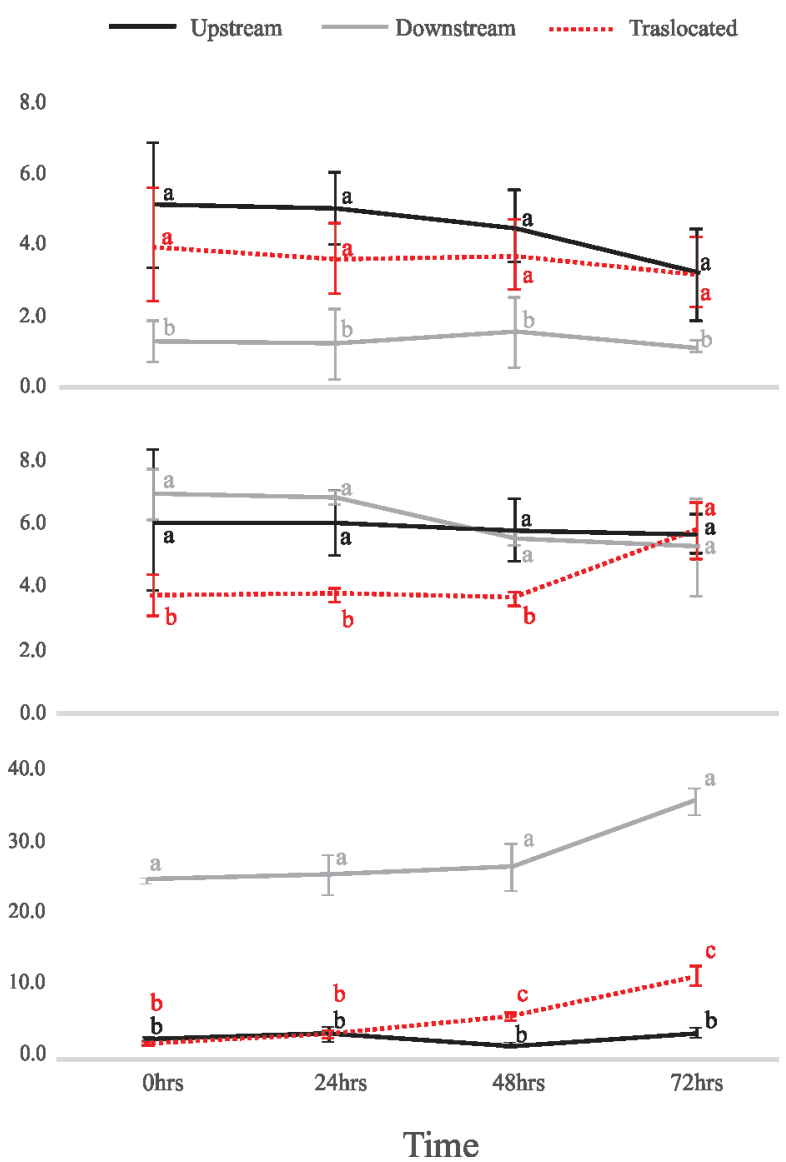

Figure 2. Mean ( $\pm \mathrm{SD}$ ) chlorophyll- $a\left(\mu \mathrm{g} \mathrm{cm}^{-2}\right)$ and bacterial density (cells $\left.\mathrm{cm}^{-2}\right)$ during the experiment in the Upstream (black solid line), Downstream (gray solid lines) and Translocated (red dotted line) treatments. Letters represent groups obtained from the post-hoc statistical analyses at each sampling time comparting between treatments. 
changes in bacterial density associated with the Treatment $_{(\text {stream) }}$ factor was strong $\left(\mu^{2}=0.77\right)$.

Mean chlorophyll-a concentration was higher in Stream $3\left(12.04 \pm 12.18 \mu \mathrm{g} \mathrm{cm}^{-2}\right)$ than in Stream $2\left(10.06 \pm 5.37 \mu \mathrm{g} \mathrm{cm}^{-2}\right)$ and than in Stream $1\left(8.27 \pm 3.98 \mu \mathrm{g} \mathrm{cm}^{-2}\right)$, although no significant differences were found between streams. Within Stream 1, chlorophyll-a concentration in the biofilms (Figure 2) were higher in the Upstream site $\left(4.45 \pm 0.86 \mu \mathrm{g} \mathrm{cm}^{-2}\right)$ than in the Downstream site $\left(1.25 \pm 0.16 \mu \mathrm{g} \mathrm{cm}^{-2}\right)$. When translocated, the chlorophyll- $a$ in the biofilm started to decrease, differing from the Upstream biofilm from $\mathrm{T} 1$ to $\mathrm{T} 3$ ( $p<0.05$, Table SII). In Stream 2, all treatments had similar chlorophyll-a concentrations regardless of the sampling date (from 4.20 to $6.11 \mu \mathrm{g} \mathrm{cm}$ $\left.{ }^{2}\right)$. In Stream 3, the chlorophyll-a concentration was over 12 -fold higher in the Downstream site $\left(27.80 \pm 5.16 \mu \mathrm{g} \mathrm{cm}^{-2}\right)$ than in the Upstream site $\left(2.05 \pm 0.81 \mathrm{\mu g} \mathrm{cm}^{-2}\right)$; the chlorophyll-a concentration in the translocated biofilm increased to 4-5 fold its original concentration after being translocated in T3-T4 (Figure 2). The effect size measures show that the significant changes in chlorophyll-a concentration regarding the analyzed factors were moderate to strong $\left(\mu^{2}>0.25\right)$.

\section{Biofilm metabolism}

ETS activity was highly variable in all treatments in the sampled streams (Figure 3). It ranged from 0.2 to $0.26 \mu \mathrm{g}$ INT-formazan $\mathrm{cm}^{-2} \mathrm{~h}^{-1}$ in Stream 1, from 0.3 to $0.33 \mu \mathrm{g}$ INT-formazan $\mathrm{cm}^{-2}$ $\mathrm{h}^{-1}$ in Stream 2 and it being significantly higher in Stream 3, ranging from 0.57 to $1.47 \mu \mathrm{g}$ INTformazan $\mathrm{cm}^{-2} \mathrm{~h}^{-1}\left(p<0.05, \mu^{2}=0.83\right.$, Table SII). There were no consistent differences in the ETS activity between Upstream or Downstream sites or in the translocated biofilms, except for an increased value at T3 in Stream 1.

$\mathrm{O}_{2}$ consumption rates were also highly variable between streams, treatments and

Table II. Nested ANOVA results for the biological variables considering Streams, Treatment (stream) and sampling Time. Significant results $(p$-value $<0.05)$ are marked with * and $\mu^{2}$ is provided as a measure of effect size.

\begin{tabular}{|c|c|c|c|c|c|c|}
\hline & & \multicolumn{5}{|c|}{ FACTORS } \\
\hline & & Stream & $\begin{array}{c}\text { Treatment } \\
\text { (stream) }\end{array}$ & Time & Stream * Time & $\begin{array}{c}\text { Time * Treatment } \\
\text { (stream) }\end{array}$ \\
\hline \multirow{3}{*}{ Bacterial density } & $F$ & 0.76 & 40.22 & 0.91 & 1.10 & 0.36 \\
\hline & $p$ & 0.51 & $<0.01^{*}$ & 0.46 & 0.40 & 0.99 \\
\hline & $\mu^{2}$ & 0.46 & 0.77 & 0.01 & 0.03 & 0.08 \\
\hline \multirow{3}{*}{ chlorophyll-a } & $\mathrm{F}$ & 1.35 & 434.66 & 15.50 & 4.67 & 4.54 \\
\hline & $\mathrm{p}$ & 0.33 & $<0.01^{*}$ & $<0.01^{*}$ & $0.01^{*}$ & $<0.01^{*}$ \\
\hline & $\mu^{2}$ & 0.94 & 0.97 & 0.75 & 0.64 & 0.53 \\
\hline \multirow{3}{*}{$\mathrm{O}_{2}$ consumption } & $\mathrm{F}$ & 8.19 & 16.97 & 22.17 & 10.00 & 8.79 \\
\hline & $\mathrm{p}$ & $0.02 *$ & $<0.01^{\star}$ & $<0.01^{*}$ & $<0.01^{\star}$ & $<0.01^{*}$ \\
\hline & $\mu^{2}$ & 0.79 & 0.59 & 0.89 & 0.88 & 0.69 \\
\hline \multirow{3}{*}{ ETS activity } & $\mathrm{F}$ & 70.03 & 2.59 & 1.28 & 1.89 & 1.16 \\
\hline & $\mathrm{p}$ & $<0.01^{*}$ & $0.02 *$ & 0.31 & 0.14 & 0.31 \\
\hline & $\mu^{2}$ & 0.83 & 0.18 & 0.06 & 0.16 & 0.23 \\
\hline
\end{tabular}


sampling times (Table I, Figure 3). Rates ranged from 0.03 to $1.39 \mathrm{mg} \mathrm{O}_{2} \mathrm{~cm}^{-2} \mathrm{~h}^{-1}$ in Stream 1, from 0.05 to $1.71 \mathrm{mg} \mathrm{O}_{2} \mathrm{~cm}^{-2} \mathrm{~h}^{-1}$ in Stream 2 and from 0.03 to $0.25 \mathrm{mg} \mathrm{O}_{2} \mathrm{~cm}^{-2} \mathrm{~h}^{-1}$ in Stream 3. In Streams 1 and 2, $\mathrm{O}_{2}$ consumption was similar in both sites, while in Stream 3 it was significantly higher in the Downstream site. The translocated biofilm increased its $\mathrm{O}_{2}$ consumption in Streams 1 and 3 at T2 $\left(p<0.05, \mu^{2}=0.69\right)$.

\section{Relationship between the biofilm} characteristics and environmental variables

Correlation analysis between biological variables and physical-chemical variables are shown in Supplementary Material - Figure S1. Bacterial density was positively correlated with SRP concentration $(R=0.81), \mathrm{BOD}_{5}(\mathrm{R}=0.74), \mathrm{COD}$ $(R=0.57)$, conductivity $(R=0.41)$ and $\mathrm{NO}_{2}^{-}(R=0.49)$. Chlorophyll-a was positively correlated with the same environmental variables, with the addition of temperature $(R=0.54)$, while also correlated to bacterial density $(R=0.79)$.

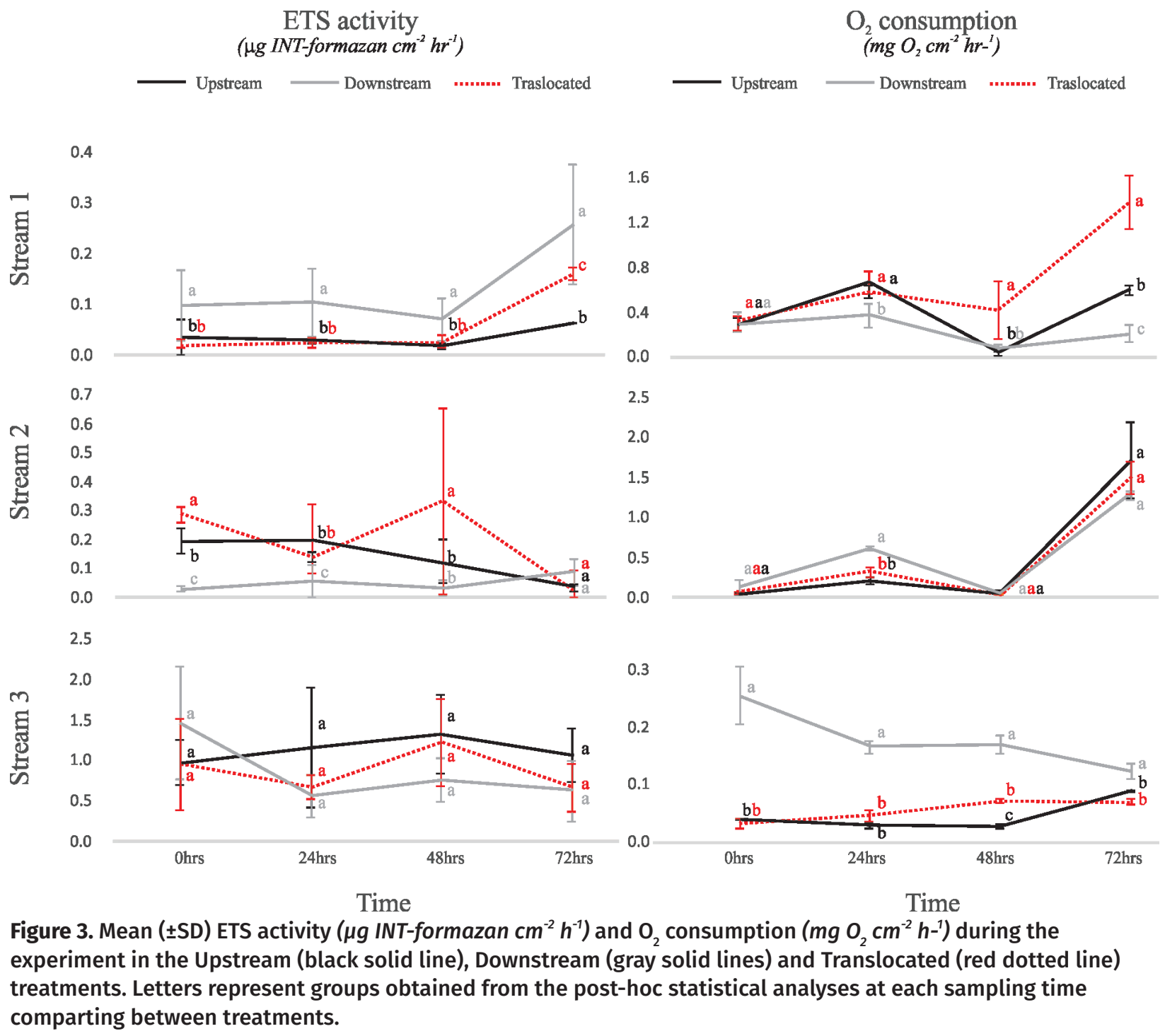


GLM modeling of the biotic variables in relation with all the physical-chemical variables measured in the water (Table SI) show that bacterial density was positively related to SRP concentration ( $t=3.57 ; p=0.02)$ and nearsignificantly to turbidity $(t=2.42 ; p=0.06)$ and $D O$ $(t=2.24 ; p=0.07)$. Chlorophyll- $a$ variations were also positively related to SRP concentration $(p=0.03)$, and near-significantly to turbidity (positively, $\mathrm{p}=0.06$ ) and to $\mathrm{pH}$ (negatively, $\mathrm{p}=0.06$ ).

Metabolic variables were not significantly related to any physical-chemical variables through the GLM modeling, although ETS variations were positively related to $B_{5}$ concentrations $(R=0.47)$ and negatively correlated to $\mathrm{NO}_{3}^{-}(\mathrm{R}=-0.56)$ and DIN $(\mathrm{R}=-0.47)$.

\section{DISCUSSION}

The results show that the structural and metabolic variables measured in the biofilm responded to the physical-chemical characteristics of the water, although they did not represent suitable indicators of shortterm environmental degradation during the translocation experiment. Nutrients and organic matter concentrations were significant factors in explaining the variations in bacterial density and chlorophyll-a, even in the nutrient-rich streams studied.

Bacterial density was a clear indicator of increased nutrients and organic matter concentration in the sites associated to urbanization. Bacterial density was always higher in the most urbanized sites, and the differences between upstream and downstream sites was also more important when the stream was more polluted. This is consistent with was reported for multiple environments under different nutrient loads (e.g. Romaní et al. 2004, Scott et al. 2008, Díaz Villanueva et al. 2011, Cochero et al. 2018), where bacterial density was increased with the addition of nutrients and/or labile organic matter.

The response of chlorophyll-a, on the other hand, was stream-specific, being higher upstream in the less polluted stream (Stream 1), but higher downstream in the more polluted streams (Stream 3). This latter is consistent with the increase in nutrients downstream in the more urbanized stream; nutrient availability is one of the most important factors in biofilm development, even in nutrient-rich streams with high contents of organic matter (Carr et al. 2005, Cochero et al. 2013). In the less urbanized streams the differences in nutrient concentration between sites were not significantly different, and a decreased algal biomass downstream can suggest either the presence of other pollutants associated with urbanization that inhibit algal growth (i.e. metals), or that the algal communities are limited by other factors, such as the bioavailability of carbon (McNamara \& Leff 2004, Hill et al. 2012). Since Pampean streams are rich in soluble phosphorous and nitrogen (Feijoó \& Lombardo 2007), microbial communities in these environments could be limited by carbon availability (Cochero et al. 2013).

Metabolic variables usually react sooner than structural characteristics to environmental impacts (Serra et al. 2009, Guasch et al. 2010b, Cornet 2012, Proia et al. 2013), and the effects are generally more evident when the biofilm from a less polluted site is exposed to heavier pollution than the other way around (Sierra \& Gómez 2010, Proia et al. 2013). In that sense, primary production of the biofilm decreased when transferred from a less polluted site to a more polluted site in a nutrient-rich stream before any changes were measurable in algal biomass (Sierra \& Gómez 2010). Our results show that the metabolic variables measured, both as the activity of the electron-transfer system and 
as sediment oxygen consumption, were highly variable endpoints throughout the experiment, not clearly allowing the discrimination between environmental impacts. Only in the most impacted site at the heavily impacted stream, the $\mathrm{O}_{2}$ consumption was linked with the higher algal biomass and bacterial density. After the translocation, the variability in ETS activity and $\mathrm{O}_{2}$ consumption in the biofilm increased, which could be linked to the stress of the translocation process, rather than a natural variation in the communities. In long term experiments, metabolic variables have shown to stabilize (Sabater et al. 2011), linking streams exposed to urban impacts to a higher heterotrophic activity in the sediment (Bukaveckas et al. 2002, Artigas et al. 2013, Aristi et al. 2015). However, respiration endpoints from the sediment should be analyzed with caution for short-term translocation experiments aimed to recognize fast changes in water quality conditions.

The use of translocation experiments has been increasingly used for communities such as diatoms (Ivorra et al. 1999, Tolcach \& Gómez 2002, Sierra \& Gómez 2010), as they can represent a powerful approach for the biomonitoring of watersheds, providing a suitable design for multiple stressor assessment. These experiments were conducted using glass, clay or acetate substrates, where biofilm can develop very differently from the existing community in the sediment (Morin et al. 2016). By using germination trays with stream sediment, we ensured that the translocated assemblage is similar to that found in the stream sediment, which can represent an advantage to further the knowledge of how sediment biofilms react to changes in environmental conditions.

To conclude, the results presented here show that even in nutrient-rich streams such as the Pampean streams, biofilms respond to differences in water quality mainly in the structural characteristics, such as chlorophyll-a and bacterial density after a 30-day colonization period. If environmental conditions change abruptly, as was simulated in this study, there are also minor changes in structural characteristics that might be indicative of environmental degradation after as little as $72 \mathrm{hs}$ of exposure. Metabolic variables, on the other hand, were more variable and influenced by the translocation process, needing a longer settling period to be considered as indicators of environmental degradation. Studies involving short-term responses in translocation experiments, involving a larger number of streams with different basal nutrient concentrations, could evolve into fast and inexpensive metrics to be used in biomonitoring programs for urbanized streams.

\section{Acknowledgments}

We thank Roberto Jensen for his help in the fieldwork. This work was funded by the Consejo Nacional de Investigaciones Científicas y Técnicas of Argentina [Grant number PIP-173]. This is ILPLA's contribution number 1190.

\section{REFERENCES}

APHA. 2017. Standard Methods for the Examination of Water and Wastewater, 23 $3^{\text {rd }}$ ed. Rice EW, Baird RB and Eaton AD (Eds). American Public Health Association, American Water Works Association, Water Environment Federation.

ARISTI I, VON SCHILLER D, ARROITA M, BARCELÓ D, PONSATÍ L, GARCÍA-GALÁN MJ, SABATER S, ELOSEGI A \& ACUÑA V. 2015. Mixed effects of effluents from a wastewater treatment plant on river ecosystem metabolism: Subsidy or stress? Freshw Biol 60: 1398-1410.

ARTIGAS J ET AL. 2013. Erratum: Global pressures, specific responses: effects of nutrient enrichment in streams from different biomes. Environ Res Lett 8: 019601.

BAUER D, DONADELLI J, GÓMEZ N, LICURSI M, OCÓN C, PAGGI A, RODRIGUES AC \& TANGORRA M. 2002. Ecological status of the Pampean plain streams and rivers (Argentina). SIL Proceedings 28: 259-262. 
BLENKINSOPP SA \& LOCK MA. 1990. The measurement of electron transport system activity in river biofilms. Water Res 24: 441-445.

BUKAVECKAS PA, WILLIAMS JJ \& HENDRICKS SP. 2002. Factors regulating autotrophy and heterotrophy in the main channel and an embayment of a large river impoundment. Aquat Ecol 36: 355-369.

CARR GM, MORIN A \& CHAMBERS PA. 2005. Bacteria and algae in stream periphyton along a nutrient gradient. Freshw Biol 50: 1337-1350.

COCHERO J, CORTELEZZI A, TARDA AS \& GÓMEZ N. 2016. An index to evaluate the fluvial habitat degradation in lowland urban streams. Ecol Indic 71: 134-144.

COCHERO J, NICOLOSI GELIS MM, SATHICQ MB \& GÓMEZ N. 2018. Biofilm early stage development in two nutrient-rich streams with different urban impacts. River Res Appl 34: 755-764.

COCHERO J, ROMANÍ A \& GÓMEZ N. 2013. Delayed response of microbial epipelic biofilm to nutrient addition in a Pampean stream. Aquat Microb Ecol 69: 145-155.

COCHRAN WG. 1951. Testing a Linear Relation among Variances. Biometrics 7: 17.

CORNET NC. 2012. The use of pulse amplitude modulated fluorescence techniques for metal toxicity assessment in fluvial biofilms. Universitat de Girona.

DELGADO C, PARDO I \& GARCíA L. 2012. Diatom communities as indicators of ecological status in Mediterranean temporary streams (Balearic Islands, Spain). Ecol Indic 15: 131-139.

DÍAZ VILLANUEVA V, FONT J, SCHWARTZ T \& ROMANI AM. 2011. Biofilm formation at warming temperature: acceleration of microbial colonization and microbial interactive effects. Biofouling 27: 59-71.

DORIGO U, LEBOULANGER C, BÉRARD A, BOUCHEZ A, HUMBERT J \& MONTUELLE B. 2007. Lotic biofilm community structure and pesticide tolerance along a contamination gradient in a vineyard area. Aquat Microb Ecol 50: 91-102.

FEIJOÓ CS, GIORGI A, GARCÍA ME \& MOMO F. 1999. Temporal and spatial variability in streams of a pampean basin. Hydrobiologia 394: 41-52.

FEIJOÓ CS \& LOMBARDO RJ. 2007. Baseline water quality and macrophyte assemblages in Pampean streams: A regional approach. Water Res 41: 1399-1410.

FOLK R. 1959. Practical Petrographic Classification of Limestones. Am Assoc Pet Geol Bull: 43.
GARNIER J \& BILLEN G. 2007. Production vs. Respiration in river systems: An indicator of an "ecological status." Sci Total Environ 375: 110-124.

GIORGI A \& MALACALZA L. 2002. Effect of an industrial discharge on water quality and periphyton structure in a pampeam stream. Environ Monit Assess 75: 107-119.

GÓMEZ N, SIERRA MV, COCHERO J, LICURSI M \& BAUER DE. 2011. Epipelic biofilms as indicators of environmental changes in lowland fluvial systems. In: Biofilms: Formation, Development and Properties, p. 259-290.

GUASCH H, GINEBREDA A \& GEISZINGER A. 2010a. Emerging and Priority Pollutants: Bringing Science into River Management Plans, Guasch H, Ginebreda A and Geiszinger A (Eds). Springer International Publishing.

GUASCH H, MARTÍ E \& SABATER S. 1995. Nutrient enrichment effects on biofilm metabolism in a Mediterranean stream. Freshw Biol 33: 373-383.

GUASCH H, SERRA A, CORCOLL N, BONET B \& LEIRA M. $2010 \mathrm{~b}$. Metal Ecotoxicology in Fluvial Biofilms: Potential Influence of Water Scarcity. In: Hdb Env Chem, p. 41-53.

HILL BH, ELONEN CM, SEIFERT LR, MAY AA \& TARQUINIO E. 2012. Microbial enzyme stoichiometry and nutrient limitation in US streams and rivers. Ecol Indic 18: 540-551.

IVORRA N, HETTELAAR J, TUBBING GMJ, KRAAK MHS, SABATER S \& ADMIRAAL W. 1999. Translocation of microbenthic algal assemblages used for in situ analysis of metal pollution in rivers. Arch Environ Contam Toxicol 37: 19-28.

KNOPP H. 1968. Stoffwechseldynamische Untersuchungsverfahren für die biologische Wasseranalyse. Int Rev der gesamten Hydrobiol und Hydrogr 53: 409-441.

LEFF LG. 2000. Longitudinal changes in microbial assemblages of the Ogeechee River. Freshw Biol 43: 605-615.

LICURSI M, GÓMEZ N \& SABATER S. 2016. Effects of nutrient enrichment on epipelic diatom assemblages in a nutrient-rich lowland stream, Pampa Region, Argentina. Hydrobiologia 766: 135-150.

LOCK MA. 1981. River Epilithon - A Light and Organic Energy Transducer. In: Perspectives in Running Water Ecology. Springer US, Boston, MA, p. 3-40.

MCNAMARA CJ \& LEFF LG. 2004. Response of biofilm bacteria to dissolved organic matter from decomposing maple leaves. Microb Ecol 48: 324-330.

MEDLEY CN \& CLEMENTS WH. 1998. Responses of diatom communities to heavy metals in streams: the influence of longitudinal variation. Ecol Appl 8: 631-644. 
MORIN S, GÓMEZ N, TORNÉS E, LICURSI M \& ROSEBERY J. 2016. Benthic Diatom Monitoring and Assessment of Freshwater Environments: Standard Methods and Future Challenges. In: Aquatic Biofilms: Ecology, Water Quality and Wastewater Treatment, p. 229.

NICOLOSI GELIS MM, COCHERO J, DONADELLI I \& GÓMEZ N. 2020. Exploring the use of nuclear alterations, motility and ecological guilds in epipelic diatoms as biomonitoring tools for water quality improvement in urban impacted lowland streams. Ecol Indic 110: 105951.

OLAPADE OA \& LEFF LG. 2005. Seasonal response of stream biofilm communities to dissolved organic matter and nutrient enrichments. Appl Environ Microbiol 71: 2278-2287.

PORTER KG \& FEIG YS. 1980. The use of DAPI for identifying and counting aquatic microflora1. Limnol Oceanogr 25: 943-948.

PROIA L. 2012. Biofilm responses to multiple stressors associated to global change in river ecosystems. Universitat de Girona.

PROIA L, CASSIÓ F, PASCOAL C, TLILI A \& ROMANÍ AM. 2012. The Use of Attached Microbial Communities to Assess Ecological Risks of Pollutants in River Ecosystems: The Role of Heterotrophs. In: Emerging and Priority Pollutants in Rivers, Springer, Berlin, Heidelberg, p. 55-83.

PROIA L, OSORIO V, SOLEY S, KÖCK-SCHULMEYER M, PÉREZ S, BARCELÓ D, ROMANÍ AM \& SABATER S. 2013. Effects of pesticides and pharmaceuticals on biofilms in a highly impacted river. Environ Pollut 178: 220-228.

RAMELOW G, MAPLES R, THOMPSON RL, MUELLER CS, WEBRE C \& BECK JN. 1987. Periphyton as monitors for heavy metal pollution in the Calcasieu River estuary. Environ Pollut 43: 247-261.

RICART M ET AL. 2010. Triclosan persistence through wastewater treatment plants and its potential toxic effects on river biofilms. Aquat Toxicol 100: 346-353.

RIER ST \& STEVENSON RJ. 2002. Effects of light, dissolved organic carbon, and inorganic nutrients on the relationship between algae and heterotrophic bacteria in stream periphyton. Hydrobiologia 489: 179-184.

RIMET F, ECTOR L, CAUCHIE HM \& HOFFMANN L. 2009. Changes in diatom-dominated biofilms during simulated improvements in water quality: implications for diatombased monitoring in rivers. Eur J Phycol 44: 567-577.

ROMANÍ AM, GIORGI A, ACUÑA V \& SABATER S. 2004. The influence of substratum type and nutrient supply on biofilm organic matter utilization in streams. Limnol Oceanogr 49: 1713-1721.

SABATER S, ARTIGAS J, GAUDES A, MUÑOZ I, URREA G \& ROMANÍ AM. 2011. Long-term moderate nutrient inputs enhance autotrophy in a forested Mediterranean stream. Freshw Biol 56: 1266-1280.

SCOTT JT, BACK J, TAYLOR JM \& KING RS. 2008. Does nutrient enrichment decouple algal-bacterial production in periphyton? J North Am Benthol Soc 27: 332-344.

SERRA A, GUASCH H, MARTí E \& GEISZINGER A. 2009. Measuring in-stream retention of copper by means of constant-rate additions. Sci Total Environ 407: 3847-3854.

SHAPIRO SS \& WILK MB. 1965. An analysis of variance test for normality (complete samples). Biometrika 52: 591-611.

SIERRA MV \& GÓMEZ N. 2010. Assessing the disturbance caused by an industrial discharge using field transfer of epipelic biofilm. Sci Total Environ 408: 2696-2705.

STRICKLAND JDH \& PARSONS TR. 1972. A Practical Handbook of Seawater Analysis. A Pract Handb seawater Anal 167: 185.

TIEN CJ, WU WH, CHUANG TL \& CHEN CS. 2009. Development of river biofilms on artificial substrates and their potential for biomonitoring water quality. Chemosphere 76: 1288-1295.

TLILI A, CORCOLL N, BONET B, MORIN S, MONTUELLE B, BÉRARD A \& GUASCH H. 2011. In situ spatio-temporal changes in pollution-induced community tolerance to zinc in autotrophic and heterotrophic biofilm communities. Ecotoxicology 20: 1823-1839.

TLILI A, DORIGO U, MONTUELLE B, MARGOUM C, CARLUER N, GOUY V, BOUCHEZ A \& BÉRARD A. 2008. Responses of chronically contaminated biofilms to short pulses of diuron: An experimental study simulating flooding events in a small river. Aquat Toxicol 87: 252-263.

TOLCACH ER \& GÓMEZ N. 2002. The effect of translocation of microbenthic communities in a polluted lowland stream. SIL Proceedings 28: 254-258.

VILCHES C. 2012. Efectos de la contaminación difusa sobre el perifiton de arroyos. Universidad Nacional de La Plata.

WALSH CJ, ROY AH, FEMINELLA JW, COTTINGHAM PD, GROFFMAN PM \& MORGAN RP. 2005. The urban stream syndrome: Current knowledge and the search for a cure. In: Journal of the North American Benthological Society, p. 706-723. 


\section{SUPPLEMENTARY MATERIAL}

\section{Table SI.}

Table SII.

\section{Figure S1.}

\section{How to cite}

COCHERO J, GELIS MMN, DONADELLI J \& GÓMEZ N. 2021. Translocation of Epipelic Biofilms and Their Short-Term Responses to Urbanization Impacts in Nutrient Rich Streams. An Acad Bras Cienc 93: e20210379. DOI 10.1590/0001-3765202120210379.

Manuscript received on March 11, 2021;

accepted for publication on May 24, 2021

\section{JOAQUÍN COCHERO}

https://orcid.org/0000-0003-3957-6819

\section{MARÍA MERCEDES N. GELIS}

https://orcid.org/0000-0001-6324-7930

\section{JORGE DONADELLI}

https://orcid.org/0000-0003-2688-0547

\section{NORA GÓMEZ}

https://orcid.org/0000-0003-0698-4007

Universidad Nacional de La Plata, Facultad de Ciencias Naturales y Museo, Instituto de Limnología “Dr. Raúl

A. Ringuelet", Consejo Nacional de Investigaciones Científicas y Tecnológicas/CONICET, Boulevard 120 y 62, No 1437, CP1900, Buenos Aires, La Plata, Argentina

Correspondence to: Joaquin Cochero

E-mail:jcochero@ilpla.edu.ar

\section{Author contributions}

Following CRediT taxonomy. Joaquín Cochero \& María Mercedes N. Gelis: Conceptualization, formal analysis, investigation, methodology, visualization and writing. Jorge Donadelli: Investigation and resources. Nora Gómez: Funding acquisition.

\section{(cc) BY}

